\title{
BAR ANALOGUES FOR MODELLING OF BUILDING STRUCTURES
}

\author{
Maria S. Barabash ${ }^{1,2}$, Andrii V. Tomashebskyi ${ }^{1,2}$ \\ 1 "LIRA SAPR" Ltd, Kiev, UKRAINE \\ ${ }^{2}$ National Aviation University, Kiev, UKRAINE
}

\begin{abstract}
This paper discusses the use of bar analogues for calculation of internal forces in the cross-sections of building structures, which are modelled by a set of finite elements. It also introduces the concepts of bar analogues, explains their basic theoretical premises and provides the results of the calculations of verification problems.
\end{abstract}

Keywords: bar analogues, finite elements, structural modeling, internal forces

\section{СТЕРЖНЕВЫЕ АНАЛОГИ ДЛЯ МОДЕЛИРОВАНИЯ СТРОИТЕЛЬНЫХ КОНСТРУКЦИЙ}

\author{
М.С. Барабаш ${ }^{1,2}$, А.В. Томашевский ${ }^{1,2}$ \\ ${ }^{1}$ ООО «ЛИРА САПР», г. КИев, УКРАИНА \\ ${ }^{2}$ Национальный авиационный университет, г. Киев, УКРАИНА
}

\begin{abstract}
Аннотация: В статье рассматривается новый подход к моделированию несущих конструкций. Подход заключается в использовании стержневых аналогов для вычисления усилий в поперечных сечениях строительных конструкций, моделируемых совокупностью конечных элементов. Вводятся понятия стержневых аналогов, разъясняются их основные теоретические предпосылки, приводятся результаты расчета верификационных задач.
\end{abstract}

Ключевые слова: стержневые аналоги, конечные элементы, моделирование конструкций, внутренние усилия

Information about the object and its stress-strain state when calculating the bearing system, as a rule, differs from the actual work of the structure. When using the finite element method for modeling, the choice of a particular type of finite element, firstly, is done in order to ensure a sufficient degree of correspondence between the mathematical model and the actual operation of the simulated structure under the given conditions [1]; secondly, it is important to correctly model the joints between the elements, which is necessary, first of all, for the analysis of the calculation results and further design. Modern software systems for strength analysis and design, such as the LIRA-SAPR software package [2], when calculating according to the classical model, make it possible to determine the internal forces arising in structural elements and use them to perform other applied calculations: for strength, stability and for the design of reinforced concrete, steel and reinforced masonry structures. The values of internal forces in structural elements are indirectly influenced by the choice of types of finite elements in modeling. Modern BIM technologies imply obtaining a design model in an automatic mode from architectural models that operate on three-dimensional structural elements. In this case, a number of load-bearing building structures such as pylons, lintel zone, deep beams, prefabricated floor slabs, diaphragms, building stiffeners, etc., can contain only lamellar and sometimes volumetric finite elements.

However, by the nature of their work, these structures are similar to the pivot ones. The cross sections of these structures are represented in the design models by a set of finite elements and nodes. For a detailed analysis of these structures, it is useful (and for applied calculations it is necessary) to determine the internal forces in their compound cross-sections, similar to the forces in the cross-sections of the rods. In the Software Package LIRA-SAPR, this problem is solved by the system "Rod analogs". 


\section{Concepts of bar analogues}

A bar analogue (Fig. 1) is a group of finite elements and their nodes, logically connected according to a certain rule that determines a special algorithm for calculating internal forces in one bar finite element. Internal forces in the design sections of the "rod analogue" are calculated not based on the displacements of its nodes, but by summing nodal reactions from sets of selected finite elements. It is assumed that each such set of finite elements forms a composite cross-section of the analyzed structure, and the nodes, reactions in which are summed up, lie in the plane of this section. Such nodes and elements will be called the original objects of the "rod analogue".

The nodal reactions (nodal forces) of a finite element mean the resultant force and the resultant moment applied at the element node, which are the impact of other model elements on the given node of this finite element.

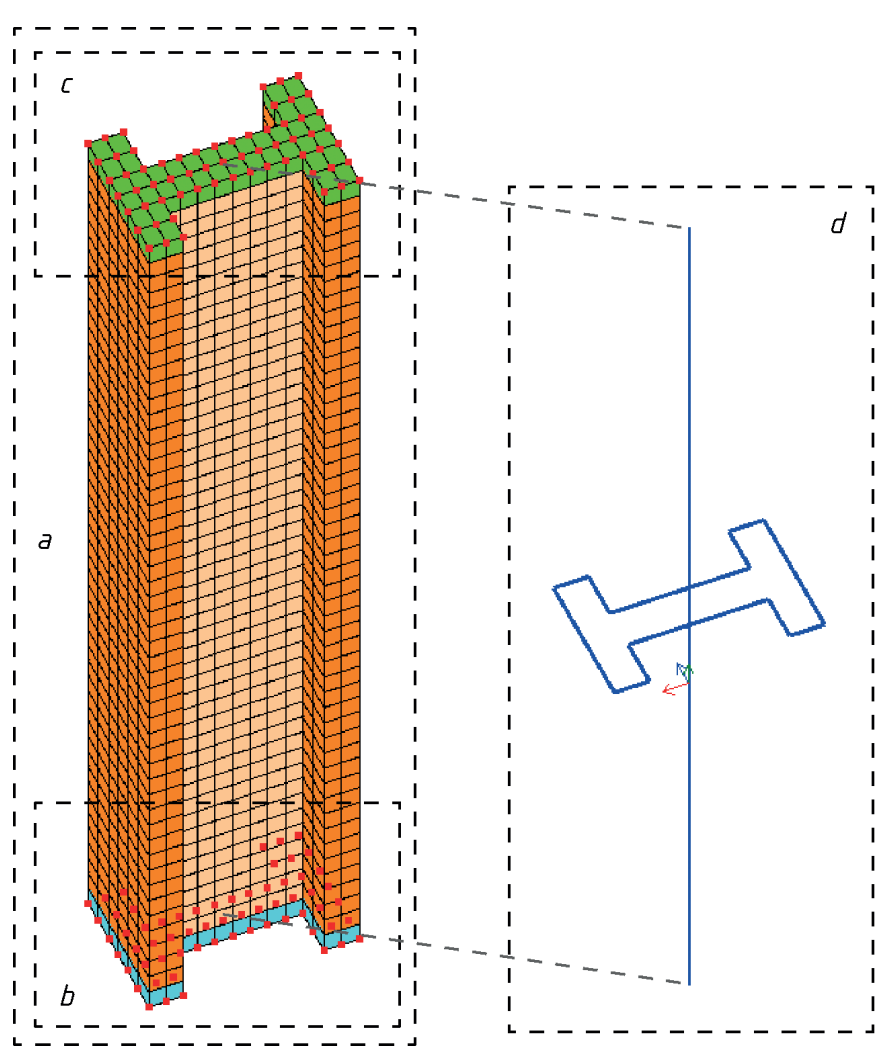

Figure 1. Bar analog: a-initial objects of the model, $b$-nodes and elements of the initial section, $c$-nodes and elements of the final section, $d$-target bar ("bar analog").
The vector of nodal reactions of the $i$-th finite element is calculated by the formula (1):

$$
\left\{R_{i}\right\}=K_{i} \cdot\left\{U_{i}\right\},
$$

where $K_{i}$ is the stiffness matrix of the $i$-th finite element, $U_{i}$ is the vector of displacements of nodes related to the $i$-th finite element.

The initial finite elements of a bar analog can be bar, plate, volumetric finite elements, special elements, as well as all kinds of their combinations. In this case, the original elements and nodes can be those for several "core analogues".

In order to determine the forces in the design sections of the "bar analogue", sets of initial nodes and elements are specified that form planar composite sections of the structure under consideration. The set that forms a composite section includes nodes lying in the plane of this section and finite elements adjacent to the section plane with nodes: rods - one node, plates - one node or edge, volumetric FE - one node, edge or face.

"Bar analogue" has two design sections - at the beginning and at the end. If the analysis of a composite structure requires a greater number of design sections along its length, then it is necessary to create a chain of bar analogues. The "bar analogue" must be in a certain position in relation to the considered composite structure: the planes of its initial and final design sections must coincide with the corresponding planes of the original composite sections of the structure.

\section{Algorithm for calculating internal forces}

Internal forces in the calculated cross-section of the "bar analogue" are calculated as follows.

1. The whole model is calculated, nodal reactions from all elements are calculated.

2 . In the composite section formed by $\mathrm{n}$ initial nodes and $\mathrm{m}$ elements, the summed nodal reactions $R_{c}$ and $M_{c}$ from these elements are calculated (Fig. 2).

2.1. The geometric center $C$ of the composite section is determined on the basis of the abutment areas $A$ with the centers of gravity $\left(x_{j} ; y_{j} ; z_{j}\right)(2)$ of the original finite elements to the plane of the composite section: for a bar, its abutment area is calculated based on the section area, for a plate-based on the plate thickness and the distance between the nodes, for a volumetric 
$\mathrm{FE}$ - as the area of the face adjacent to the plane of the composite section.

$$
\begin{gathered}
x_{C}=\frac{\sum_{j=1}^{m}\left(A_{j} x_{j}\right)}{\sum_{j=1}^{m} A_{j}} ; y_{C}=\frac{\sum_{j=1}^{m}\left(A_{j} y_{j}\right)}{\sum_{j=1}^{m} A_{j}} ; \\
z_{C}=\frac{\sum_{j=1}^{m}\left(A_{j} z_{j}\right)}{\sum_{j=1}^{m} A_{j}} .
\end{gathered}
$$

2.2. Nodal reactions from the initial elements $-R_{i j}$ (4) and $M_{i j}(5)$ - in the composite section are summed taking into account the shoulder $d$ (3) between the node point $N_{i}$ and the geometric center of the section $C$.

$$
\begin{gathered}
d_{x}=x_{i}-x_{C} ; \quad d_{y}=y_{i}-y_{C} ; \quad d_{z}=z_{i}-z_{C} ; \\
R_{x c}=\sum_{i=1}^{n} R_{x i j} ; \quad R_{y c}=\sum_{i=1}^{n} R_{y i j} ; \quad R_{z c}=\sum_{i=1}^{n} R_{z i j} ; \\
M_{x c}=\sum_{i=1}^{n} \sum_{j=1}^{m}\left(M_{x i j}-R_{y i j} d_{z}+R_{z i j} d_{y}\right) ; \\
M_{y c}=\sum_{i=1}^{n} \sum_{j=1}^{m}\left(M_{y i j}-R_{z i j} d_{x}+R_{x i j} d_{z}\right) ; \\
M_{z c}=\sum_{i=1}^{n} \sum_{j=1}^{m}\left(M_{z i j}-R_{x i j} d_{y}+R_{y i j} d_{x}\right) .
\end{gathered}
$$

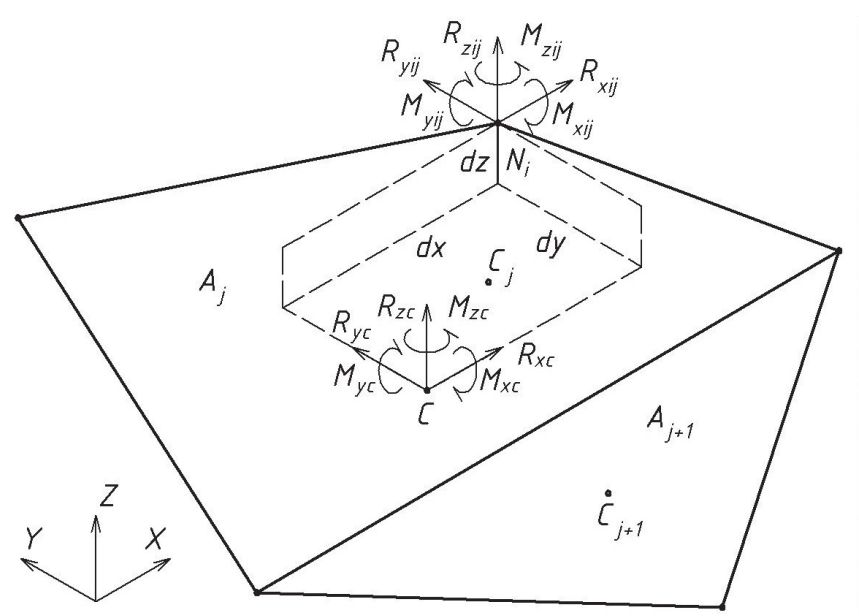

Figure 2. Calculation of the summed nodal reactions

3. The summed nodal reactions reduced to the center of the composite section are interpreted as internal forces in the corresponding design section of the target bar by converting from the global coordinate system to the local coordinate system of the composite section. The local coordinate system of a compound section is defined as a coordinate system with origin at the geometric center of the compound section and axes parallel to the local axes of the target bar.

\section{Scope of "bar analogues"}

"Bar analogues" in SP LIRA-SAPR can be used to determine internal forces at

1. linear static and dynamic calculations, except for time-history dynamic analysis [3],

2. nonlinear calculations at the last stage of loading (full load) [3],

3. calculations using engineering nonlinearity techniques $[4,5,7]$,

4. calculations with a changing design scheme (modeling of installation and dismantling processes), provided that all the original elements of the bar analogue have the same stages of assemblage and disassemblage (target bars are recommended not to be included in the process of changing the design scheme or to be determined at the same stages of assemblage and disassemblage, as the original objects of the corresponding rod analogs) $[6,7,8]$.

A "bar analog" can be a two-node finite element of any type, except for special ones, which allows solving problems with various characteristics of the scheme. By default, when creating a "bar analogue", FE type 10 is used - universal spatial bar FE.

\section{Calculation of "bar analogues" in SP LIRA-SAPR}

Calculation of "bar analogues" occurs when performing a complete calculation of the model at its final stage. The result of the calculation of "bar analogues" are the forces obtained in their design sections, calculated for all loadings. The forces obtained should not be interpolated along the length of the "bar analogues"; they are valid only at the points of its initial and final design sections. This should be taken into account when viewing the calculation results in the form of diagrams, or use the presentation of forces in the form of mosaics and / or in tabular form.

The calculated internal forces in the sections of the "bar analogues" are further used to determine the forces for the calculated combinations of loads and forces, as well as in the operation of the structural systems. 


\section{Verification problems}

Let's consider examples of verification problems that can illustrate the operation of the "bar analogues" system in the LIRA-SAPR software package.

\section{Problem No. 1.}

We consider a vertical cantilever bar with a square cross section, loaded with axial and transverse concentrated loads at the free end (Fig. 3).

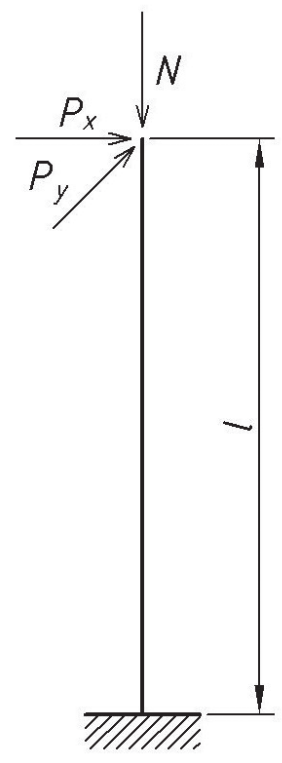

Figure 3. Design scheme for problem No. 1

Elasticity modulus is $E=3.0 \cdot 10^{7} \mathrm{~Pa}$; Poisson's ratio is $\mu=0.2$; length of the bar is $l=10 \mathrm{~m}$; cross section dimensions are $b=h=0.5 \mathrm{~m}$; axial force that acts along axis $X, P_{x}=10 \mathrm{kN}$; сосредоточенная сила, действующая вдоль оси $Y, P_{y}=10 \kappa \mathrm{H}$; transverse force that acts along axis $Z, N=10000 \mathrm{kN}$.
It is necessary to determine the internal forces in the support cross-section of the bar.

The solution to the problem is presented in [9]. For non-deformed schemes, the axial force from a vertical load, as well as shear forces and bending moments from horizontal loads, are calculated by the formulas (6):

$$
\begin{gathered}
N(0)=N ; \\
Q_{x}(0)=P_{x} ; \quad Q_{y}(0)=P_{y} ; \\
M_{x}(0)=P_{y} l \quad M_{y}(0)=P_{x} l .
\end{gathered}
$$

When calculating in SP LIRA-SAPR, three design models were considered. These models were made of finite elements of various types: bar FE 10 (universal spatial bar FE); shell FE 48 (universal quadrangular FE shell with intermediate nodes on the sides); volumetric FE 35 (universal spatial eight-nodal isoparametric FE with intermediate nodes on the sides). In models of shell FE, a $4 \times 10 \mathrm{FE}$ mesh is used, and for volumetric models, a $4 \times 4 \times 10 \mathrm{FE}$ mesh. Also bar analogues for determining the forces were created. The calculation results are presented in table. 1 . The forces in the "bar analogues" correspond to the forces calculated from the model from the bar FE 10.

\section{Problem No. 2.}

A beam clamped at the ends and loaded with a uniformly distributed load $q$ (Fig. 4) is given.

Elasticity modulus is $E=3.0 \cdot 10^{7} \mathrm{~Pa}$; Poisson's ratio is $\mu=0.2$; beam length is $l=2.4 \mathrm{~m}$; the width of the cross section is $b=0.2 \mathrm{~m}$; the height of the cross section is $h=0.3 \mathrm{~m}$; load is $q=10 \mathrm{kN} / \mathrm{m}$.

It is necessary to determine the internal forces at the characteristic points of the beam.

Table 1. Results of calculating problem No. 1

\begin{tabular}{|c|c|c|c|}
\hline The sought value & Bar solution & \multicolumn{2}{|c|}{ Solution using bar analogues } \\
\hline \multirow{2}{*}{ Axial forces $N(0), \mathrm{kH}$} & \multirow{2}{*}{10000.00} & FE 48 & 10000.00 \\
\cline { 3 - 4 } & & FE 35 & 10000.00 \\
\hline \multirow{2}{*}{ Shear forces $Q_{x}(0), Q_{y}(0), \mathrm{kN}$} & \multirow{2}{*}{10.00} & FE 48 & 10.00 \\
\cline { 3 - 4 } & & FE 35 & 10.00 \\
\hline \multirow{2}{*}{ Bending moments $M_{x}(0), M_{y}(0), \mathrm{kN} \cdot \mathrm{m}$} & \multirow{2}{*}{100.00} & FE 48 & 100.00 \\
\cline { 3 - 4 } & & FE 35 & 100.00 \\
\hline
\end{tabular}


The solution to the problem is presented in [9]. Support reactions $R_{A}, R_{B}, M_{A}, M_{B}$, shear force $Q$, bending moment $M$, internal forces in characteristic sections are calculated by the formulas (7):
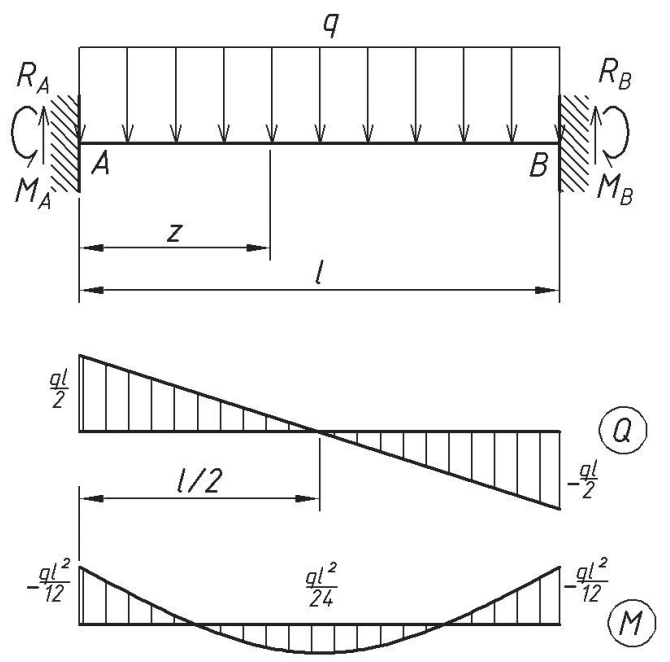

Figure 4. Design scheme for problem No. 2

$$
\begin{gathered}
R_{A}=R_{B}=\frac{q l}{2} ; \quad M_{A}=M_{B}=\frac{q l^{2}}{12} ; \\
0 \leq z \leq l: \\
Q(z)=\frac{q l}{2}\left(1-2 \frac{z}{l}\right) ; \\
M(z)=\frac{q l^{2}}{2}\left(\frac{z}{l}-\frac{z^{2}}{l^{2}}-\frac{1}{6}\right) ; \\
Q(0)=\frac{q l}{2} ; \quad Q(l)=-\frac{q l}{2} ; \\
M(0)=M(l)=-\frac{q l^{2}}{12} ; \quad M(l / 2)=\frac{q l^{2}}{24} .
\end{gathered}
$$

When calculating in SP LIRA-SAPR, several computational models were considered made of finite elements of various types: bar FE 10 (universal spatial bar FE), plate FE 21 (rectangular FE of a plane problem (beam-wall) and plate FE 28 (rectangular FE strain problems (deep beam) with intermediate nodes on the sides). In the models of plate FE, a $16 \times 6 \mathrm{FE}$ mesh is used, and bar counterparts are also created to determine the forces.

The calculation results are presented in table. 2 . The forces in the target members of the bar analogues sufficiently correspond to the forces calculated from the corresponding models from the bar FE 10.

\section{CONCLUSIONS}

The use of "bar analogues" in FE-models in some cases may be the most acceptable approach for the automated design of elements whose work is close to the work of rods. So, when designing a lintel, reinforcement should be placed at the upper and lower edges of the element, when designing a column - it's preferably at the corners of its cross section. Regulatory requirements guide engineers to select reinforcement based on integrated forces in bar cross sections. On the basis of the stressstrain state of a bulkhead or a column, obtained from a model from flat finite elements, the selection of reinforcement is very problematic.

Bar analogues also indirectly solve the problem of taking into account the stress concentration at the support points and other points of singularity. Determination of stresses at nodes of finite elements is always associated with a loss of accuracy. For "bar analogues" this problem is integrally solved automatically, since the equilibrium is always observed.

In conclusion, we note that the system "bar analogues" of the LIRA-SAPR software package is a useful tool for the analysis and applied calculations of structural elements. Many areas of its application have yet to be determined in engineering practice.

Table 2. Results of calculating problem No. 2

\begin{tabular}{|c|c|c|c|}
\hline The sought value & \multirow{2}{*}{ Bar solution } & \multicolumn{2}{|c|}{ Solution using bar analogues } \\
\hline \multirow{2}{*}{ Shear force in the support $A, \mathrm{kN}$} & \multirow{2}{*}{12.00} & FE 21 & 12.00 \\
\cline { 3 - 4 } & & FE 28 & 12.00 \\
\hline Bending moment in the support $A, \mathrm{kN} \cdot \mathrm{m}$ & \multirow{2}{*}{-4.80} & FE 21 & -4.77 \\
\cline { 3 - 4 } & & FE 28 & -4.79 \\
\hline \multirow{2}{*}{ Bending moment in the middle point of the span, $\mathrm{kN} \cdot \mathrm{m}$} & \multirow{2}{*}{2.40} & FE 21 & 2.43 \\
\cline { 3 - 4 } & & FE 28 & 2.41 \\
\hline
\end{tabular}




\section{REFERENCES}

1. Metod konechnykh elementov: teoriya i chislennaya realizatsiya [The finite element method: theory and numerical implementation] / Gorodetskiy A.S., Yevzerov I.D., Strelets-Streletskiy Ye.B. et al. - Kiev: Fakt, 1997. - 138 p. - (Programmnyy kompleks LIRA-Windows).

2. Gorodetskiy A.S. Programmnyy kompleks LIRASAPR 2013. Uchebnoye posobiye [Software complex LIRA-SAPR 2013] / Gorodetskiy D.A., Barabash M.S., Vodop'yanov R.YU. Et al.; under ed. Acad. Of RAACS Gorodetskiy A.S. - M., 2013. - $376 \mathrm{p}$.

3. Gorodetskiy A.S. Komp'yuternyye modeli konstruktsiy [Computer models of structures] / A.S. Gorodetskiy, I.D. Yevzerov. - [2-nd edition.] - Kiyev: "FAKT", 2007. - 394 p.

4. Uchet nelineynoy raboty zhelezobetonnykh konstruktsiy v prakticheskikh raschetakh [Accounting for nonlinear work of reinforced concrete structures in practical calculations] / Gorodetskiy A.S., Barabash M.S. // Stroitel'stvo, materialovedeniye, mashinostroyeniye// Proceedings. - Dnepropetrovsk: PGASA, 2014. - Vol. 77. - P. 54-59.

5. Printsip «Opredelyayushcheye nagruzheniye» [Principle "Defining loading"] / Gorodetskiy A.S., Barabash M.S., Romashkina M.A., Tomashevskiy A.V. // International Journal for Computational Civil and Structural Engineering. - 2020.- Vol. 16. - Issue 2. - P. 50-63.

6. Barabash M.S. Komp'yuternoye modelirovaniye protsessov zhiznennogo tsikla ob"yektov stroitel'stva: Monografiya [Computer modeling of the life cycle processes of construction objects] / Mariya Sergeyevna Barabash. - K.: «Stal'», 2014. - $301 \mathrm{p}$

7. Barabash M.S Uchet nelineynoy raboty zhelezobetona v PK LIRA-SAPR. Metod «Inzhenernaya nelineynost'» [Accounting for nonlinear work of reinforced concrete in the LIRA-SAPR software package. Method "Engineering nonlinearity] / M.S. Barabash, A.S. Gorodetskiy // International Journal for Computational Civil and Structural Engineering. - 2016. - Vol. 12. - Issue 2. - P. 92-98.

8. Komp'yuternoye modelirovaniye protsessa vozvedeniya stroitel'nykh konstruktsiy [Computer modeling of the process of erection of building structures] / Gorodetskiy A.S., Barabash M.S. // Stroitel'naya mekhanika i raschet sooruzheniy. 2014. Vol. 5 (256). - P. 28-33.

9. Pisarenko G.S. Spravochnik po soprotivleniyu materialov [Handbook on the strength of materials] / Pisarenko G.S., Yakovlev A.P., Matveyev V.V.; corr. red. Pisarenko G.S. - 2-nd edition, remastered and added. - Kiyev: Naukova dumka, 1988. - $736 \mathrm{p}$.

\section{СПИСОК ЛИТЕРАТУРЫ}

1. Метод конечных элементов: теория и численная реализация / Городецкий А.С., Евзеров И.Д., Стрелец-Стрелецкий Е.Б. и др. - К. Факт, 1997. - 138 с. - (Программный комплекс ЛИРА-Windows).

2. Городецкий А.С. Программный комплекс ЛИРА-САПР 2013. Учебное пособие / Городецкий Д.А., Барабаш М.С., Водопьянов Р.Ю. и др.; под ред. академика РААСН Городецкого А.С. - М., 2013. - 376 с.

3. Городецкий А.С. Компьютерные модели конструкций / А.С. Городецкий, И.Д. Евзеров. [2-е изд., доп.] - Киев: "ФАКТ", 2007. - 394 с.

4. Учет нелинейной работы железобетонных конструкций в практических расчетах / Городецкий А.С., Барабаш М.С. // Строительство, материаловедение, машиностроение // Сб. научн. трудов. - Днепропетровск: ПГАСА, 2014. - Вып. 77. - С. 54-59.

5. Принцип «Определяющее нагружение» / Городецкий А.С., Барабаш М.С., Ромашкина М.A., Томашевский А.B. // International Journal for Computational Civil and Structural Engineering. - 2020. - Vol. 16. - Issue 2. P. 50-63.

6. Барабаш М.С. Компьютерное моделирование процессов жизненного цикла объектов строительства: Монография / Мария Сергеевна Барабаш. - К.: «Сталь», 2014. - 301 с

7. Барабаш М.С. Учет нелинейной работы железобетона в ПК ЛИРА-САПР. Метод «Инженерная нелинейность» / М.С. Барабаш, А.С. Городецкий // International Journal for Computational Civil and Structural Engineering. - 2016. - Vol. 12. - Issue 2. - P. 92 - 98. 
8. Компьютерное моделирование процесса возведения строительных конструкций / Городецкий А.С., Барабаш М.С. // Строительная механика и расчет сооружений: Научно-технический журнал. - Москва: ЦНИИСК им. В. А. Кучеренко, 2014. - Вып. 5 (256). - С. 28-33.
9. Писаренко Г.С. Справочник по сопротивлению материалов / Писаренко Г.С., Яковлев А.П., Матвеев В.В.; отв. ред. Писаренко Г. С. - 2-е изд., перераб. и доп. - Киев: Наукова думка, 1988. - $736 \mathrm{c}$.

Maria S. Barabash - Academician of the Academy of Construction of Ukraine, Doctor of Technical Sciences, Professor, Professor of Computer Technologies of Construction Department, National Aviation University Director of “LIRA SAPR" Ltd, 7a, Kiyanovsky side street (pereulok), Kiev, 04053, Ukraine; phone: +38 (095) 286-39-90; e-mail: bmari@ukr.net, www.liraland.com ORCID ID: 0000-0003-2157-521X,

Researcher ID: R-9181-2016

Барабаш Мария Сергеевна - академик Академии строительства Украины, доктор технических наук, профессор, профессор кафедры компьютерных технологий строительства Национального авиационного университета, директор ООО «ЛИРА САПР», 04053, Украина, Киев, пер. Кияновский, д.7-а;

e-mail: bmari@ukr.net,www.liraland.com

ORCID ID: 0000-0003-2157-521X,

Researcher ID: R-9181-2016

Andrii V. Tomashevskyi - postgraduate student, Computer Technologies of Construction Department, National Aviation University; software engineer "LIRA SAPR” Ltd, 7a, Kiyanovsky side street (pereulok), Kiev, 04053, Ukraine; phone: +38 (096) 225 38 42, e-mail: tomashevsky.a.v@gmail.com,

ORCID ID: 0000-0001-5960-2100

Томашевский Андрей Владимирович - аспирант кафедры компьютерных технологий строительства Национального авиационного университета; инженер-программист ООО «ЛИРА САПР», 04053, Украина, Киев, пер. Кияновский, д.7-а; тел.: +38 (096) 22538 42, e-mail: tomashevsky.a.v@gmail.com,

ORCID ID: 0000-0001-5960-2100 